\title{
The Impact of Labour Force Reduction on the Financial Performance of Manufacturing Companies
}

\author{
Wadesango $\mathrm{N}^{1 *}$., Gwangwadza D. C²., Mhaka C²., Wadesango V. $\mathrm{O}^{1}$. \\ ${ }^{1}$ University of Limpopo, Turflop Campus, Republic of South Africa \\ 2Midlands State University, Gweru, Zimbabwe \\ *newman.wadesango@ul.ac.za
}

\begin{abstract}
This study attempts to corroborate the impact of labour force reduction on financial performance of manufacturing companies in a developing country. Despite the on-going use of labour force reduction, literature and research on this approach continues to yield mixed results. This desktop research was therefore conducted with the aim of determining the impact of employing labour force reduction initiatives on financial performance of manufacturing companies. The study reviews the results and findings of empirical and qualitative literature on labour force reduction by previous scholars for a period of 6 years ranging from 2012 to 2017. The phenomenon of labour force reduction has facilitated the research and studies on the area in the past six years, with researchers reaching different conclusions on the practise's effect on organisations. This has prompted the researchers of this study to critically study labour force reduction methods, factors affecting their success, employees' reaction to the strategy, the practise effect on productivity and the relationship between labour force reduction and organisation performance.
\end{abstract}

Keywords: Labour force, financial performance, manufacturing company, reduction

\section{Introduction}

George (2014) defines the term labour force reduction as the process of eliminating jobs within an organisation but not necessarily accompanied with the dismissal of the job incumbents with the goal of improving firm's performance. Labour force reduction is often used interchangeably with terms such as retrenchment or redundancy but, while it frequently works hand in hand with those processes, it is not limited to those processes but can be achieved through alternative restructuring activities such as outsourcing, recruitment freeze, furloughs, short time working and pay cuts (Braegger et al., 2015).This study attempts to corroborate the impact of labour force reduction on financial performance of manufacturing companies in a developing country. As already alluded to in the abstract, despite the on-going use of labour force reduction, literature and research on this approach continues to yield mixed results. This study therefore will explore the methods of labour force reduction implemented by organisations in order to shed more light on what literature and other scholars have found to be its effects on financial performance of a company.

\section{Methodology}

This study adopted a desktop research approach. Desktop research refers to secondary data or that which can be collected without fieldwork. In most cases it is the research technique which is mainly acquired by sitting at a desk. In the context of this study, the term is widened to include all sources of information that do not involve a field survey. In this study therefore, literature was gathered from libraries, the internet., company documents and journal articles.

\section{Labour Force reduction methods implemented}

"To stay afloat companies have to cut costs by announcing layoffs" (Gensler, 2016). The National Social Security Authority of Zimbabwe has retrenched fifteen middle managers as it streamlines it operations (Mugabe, 2017). Air Zimbabwe retrenched 200 employees out of 424 employees (Mugabe, 2017). Statements around Labour force reduction have dominated the business papers and labour force reduction has been integrated into the life of organisations seeking survival and improved profit. Organisations take the downsizing route to reduce costs, adjusting their organisational structures making them leaner and efficient work places (George, 2014). George (2014) defines the term labour force reduction as the process of eliminating jobs within an organisation that are often but not necessarily accompanied with the dismissal of the job incumbents with the goal of improving firm performance. Labour force reduction is often used 
interchangeably with terms such as retrenchment or redundancy but, while it frequently works hand in hand with those processes, it is not limited to those processes but can be achieved through alternative restructuring activities such as outsourcing, recruitment freeze, furloughs, short time working and pay cuts (Braegger et al., 2015).

Layoffs: Ivancevich and Konopaske (2013) as well as Pearce and Robinson (2015) point out that reducing the number of employees in an organisation is the focal point of layoff strategy aimed at reducing the number of employees in order to stem survival in predicaments threatening the survival of an organisation. Vapnek (2017) asserts that laying off employees is a quick way of cutting labour related costs when an entity is failing to be competitive. This notion is supported by organisational turnaround literature such as the work by Brauer and Laamanen (2014); Tangpong et al. (2015) who suggest that downsizing exercises such as layoffs can indeed assist an entity to successfully restore its financial performance. Yu et al. (2013) stress that timely manpower adjustment strategies such as layoffs are optimal for improving output performance for an organisation facing communication difficulties. This is supported by Anderson and Lewis (2014) who emphasized the surfacing of efficient communication and diminished bureaucracy after implementing layoffs as labour force reduction strategies which disrupt the normal pattern of behaviour. De Meuse and Dai (2013) aver that layoffs assist organisations to improve their financial performance in the long term.

In light of the benefits associated with layoffs as a downsizing option to resuscitate performance, Ndofor et al. (2013) reached a different conclusion emphasizing how retrenchment practises such as layoffs are detrimental to performance. Ndofor et al. (2013) are backed by Powell and Yawson (2012) and Zorn et al. (2017) who accentuate that organisations that exercise layoffs as a labour force reduction exercise are likely to exit industries through bankruptcy further adding that layoffs diminish the survival likelihood of an organisation irrespective of the configuration of the organisation involved. Habel and Klarmann (2015) assert that organisational employee reduction is correlated to decline in customer satisfaction especially in labour intensive organisations. An additional short fall pointed out by scholars is the fact that for layoffs to improve efficiency, it must be misunderstood by employees and this results in shattered employee (Goesaert et al., 2015; Rehman and Naeem, 2012). Richter and Konig (2017) assert that the method of labour force reduction through layoffs boils down to the employer's perception of fairness and labour legislation strictness and has no significant effect on the performance of an organisation. In the same vein, Hamed et al. (2013) and Gandolfi (2013) alluded that Labour force reduction has no significant effect on the performance of an organisation. It appears that literature and research on the outcomes of layoff strategy has found mixed results over the years.

Furloughs (Unpaid Leave): Vapnek (2017) brings to light the effectiveness of furloughs as a labour reduction strategy as it reduces expenditure by placing employees in a non-work and non-pay position when faced with discontinuous events such as natural disasters or economic calamity. Zvonicek (2012) emphasizes that having employees take unpaid leave is an effective cost cutting measure as payroll costs constitute the bulk of operating expenditure incurred by organisations. Vapnek (2017) concurs pointing out how reducing the number of hours worked assists an organisation to ensure that hours worked are productive and to reduce labour related costs thereby enhancing profitability and competitiveness of an organisation. Employees found time off work to be beneficial and found the exercise to be reasonable in times of economic distress. Furloughed employees had job satisfaction and job meaningfulness when they returned to work after unpaid leave (Zvoniocek, 2012). Furloughs send clear messages to employees that they are valuable to the employer and the employer is doing all they can to keep them employed as opposed to the option of laying off employees. Furloughs help an organisation to avoid severance and rehiring costs associated with layoffs and retrenchment (Zvonicek, 2012).

Although the method of furloughs is implemented by organisations, it has its draw backs. Halbesleben et al. (2013) point out how furloughs have a significant negative effect on employees as it leads to high emotional exhaustion and low performance at work. Furloughs are associated with augment turnover rates and lower production efficiency per employee due to employees diminished organisational commitment and organisation citizenship behaviour (Shepherd, 2017). Halbesleben et al. (2013) assent that emphasizing furloughs in organisations increases turnover intentions among high performing employees, the very employees an organisation would prefer to keep. Furloughs steer employees to distancing themselves from 
the organisation, shifting their identification from work directing it more towards their families. This outcome raises concerns among entities seeking to control its labour force through furloughs (Halbesleben et al., 2014).

Fraher (2013) asserts that furloughed workers experience increased stress and distraction at work leading to increased mistakes and poor performance resulting in deteriorating productivity and wastages at work. Employees stress results from worries that the employer might employ permanent labour force reduction methods such as layoffs (Shepherd, 2017). Ko and Yeh (2013) suggest that nonstandard work engagements such as furloughs are associated with declined job satisfaction and motivation among surviving employees who are at the core of an organisation's success. Rehman and Naeem (2012) stress that labour force reduction practises such as furloughs destroy employee's perception about their job security and commitment to the organisation. All organisations are confronted with operational predicaments when the economy becomes challenging. Furloughs need strategic focus tied with sound HR policies as employees are crucial resources to an organisation (Bellairs et al., 2014). Researchers have also found downsizing to have no significant effect on employees and the organisation. Lee and Sanders,2013) avouch that although furloughs have financial and job satisfaction implications on employees, furloughs have no notable effect on individual employees' productivity and performance.

Outsourcing: Antonioli et al. (2015), Agrawal and Hall (2014) and Agrawal and Haleem (2013) concur that outsourcing is a labour force reduction strategy that assists an organisation to reduce costs and improve production efficiency in production and the quality of products. There is a significant positive relationship between outsourcing and industrial productivity and innovation process performance. The positive relationship is accompanied with cost savings and cost efficiency (Arvanitis and Loukis, 2012). This is supported by Antonioli et al. (2015) who emphasized that externalisation of high value added activities such as research and development and HRM results in productivity growth. Oke and Onwuegbuzie (2013) emphasized that outsourcing ameliorates an organisation's product innovativeness as externally contracted service providers seek to advance and differentiate their services to maintain their service contract. Despite the benefits associated with outsourcing, scholars have uncovered the costs associated with the practice. Han and Mithas (2013), highlighted how outsourcing decreases the cost of the service outsourced. However, the practise increases other organisational costs associated with the service or production process outsourced and Wickford (2016) asserts that outsourcing is associated with job loss fear and employee insecurity which deters productivity among employees proving detrimental to an organisation. Outsourcing low value added services has a negative effect on productivity further adding that turning fixed expenses into variable costs by moving low value added activities such as ancillary services outside an organisations borders does not result in cost saving (Antonioli et al., 2015). Cuillan and Andi -Zheng (2017) assert that outsourcing certain activities results in time lags for related activities lasting as long as three days, illustrating how outsourcing can cripple the efficiency of product and service delivery to customers.

Certain scholars have taken a neutral stance on the subject of downsizing with Zvonicek (2012) suggesting that outsourcing production processes does not reduce the COGS. The tendency is that costs are merely transferred from one COGS class to another. When core organisational processes are outsourced the costs saving associated with outsourcing are crippled by the organisational adaptability sacrificed. Outsourcing production process leaves adaptation to production and market trends to the service provider which can prove to be detrimental negating the cost saving aspect (Weigelt and Sarkar, 2012). Zvonicek (2012) emphasizes that outsourcing on its own has no effect on the quality of the final product surfacing the need to pay attention to enforcement of contracts as the determinant of benefits associated with out sourcing. Ho and Wei (2016) support the notion that outsourcing in itself has no effect on the quality of the product suggesting that quality is a matter of perception to the outsourcing organisation. Outsourcing can produce negative, positive, insignificant, mixed or moderate benefits to an organisation (Lahiri, 2016).

Organisation redesigning through delayering: Brauer and Laamanen (2014) outline that a labour force reduction alternative can improve the performance or an entity. Lahiri (2016) asserts that organisation redesigning is an effective labour force reduction technique with the perks of cutting costs while maintaining the capacity of an organisation. Unlike out write layoffs which piles more work on fewer employees, organisational redesigning focuses on the jobs, work units and organisational plan (Kavadis and Castañer, 
2015). Yu et al. (2013) emphasize that redesigning an organisation and delayering tall structures within an organisation assist the organisation to attain swift communication within and across departments facilitating efficient productivity. Brauer and Laamanen (2014) assert that small scale redesigning leads to efficiency improvements within the organisation without disturbing existing organisational routines. Brauer and Laamanen (2014) further added that large scale redesigning is more advantageous as it involves fundamental recreation of routines resulting in enhanced positive outcomes.

Despite the on-going use of organisational restructuring, organisational change scholars, Miller et al. (2012) outline the negative effects of organisational change on employee morale and motivation and ultimately the firm as it disrupts the normal way of doing things, as employees encounter challenges to unlearn prior lines of conduct and discover and develop new work routines. This notion is supported by Bryson et al. (2013) who emphasize that change when approached reactively to factors such as financial constraints or impending losses faced by an organisation will result in questioning employees and destroy morale. Redesigning organisations tempers with the informal structure of an organisation disrupting the informal flow of efficient communication (Schenkel and Teigland, 2016). Zvonicek (2012) asserts that survivors of organisational redesigning tend to view their organisation as less than a superlative employer increasing the turnover intent in the surviving employees resulting in knowledge loss in the form of employee exits to the organisation. Survivors of the organisational redesigning are diverted to focusing on acquiring and transferring knowledge as opposed to the preferred scenario of employees applying knowledge which they already have resulting in inferior productivity and diminishing efficiency (Anderson ad Lewis, 2014; Holton and Burch, 2016).

Although restructuring through delayering reduces payroll costs, the cost savings enjoyed are mitigated by the lower productivity of the demoted employees (Fraher, 2013 and Goesaert, Heinz and Vanormelingen, 2015). The success of an organisation after restructuring activities such as delayering can prove to be disruptive to the normal pattern of doing things. However, a well-educated team moderates the effects of downsizing as they take up the challenge to do things differently (Ahn, 2015). Restructuring can be detrimental in the short run as the practise leads to an organisation losing its routine and transitive memory. However, the practise enables cheaper novices within the organisation to take charge and bring about change and productivity required in the long run. Contextual factors such as workforce configuration and organisational culture help moderate the effect of delayering (Datta and Basuil, 2015).

\section{Factors affecting the implementation of Labour Cost reduction methods}

The successful implementation of labour cost reduction methods perpetually involves a careful consideration and management of the relationship between an organisation and its employees alongside effective communication related to the imminent changes and their implications to the employee from the employees stand point (Datta and Basuil, 2015). The interaction between effective communication and employee involvement is critical to the outcome of labour force reduction exercises (Datta and Basuil, 2015). The following sub headings will review organisational change and labour force cost reduction literature paying particular attention to organisational downsizing and restructuring.

Employee involvement: Employee involvement is an effective tool to overcome the hurdle of resistance to change by assisting the organisation to calm employees' fears over restructuring by actively engaging them in the process (Sahoo, 2014; Ashman, 2016; Boddy, 2016; Garcia et al., 2014). Employee participation program such as employee committees, suggestion schemes and interactive discussion help reduce misconceptions and misunderstanding among employees mitigating the spread of falsified rumours (Sahoo, 2014; Appelbaum et al., 2017). Zvonicek (2012) asserts that the success of organisational restructuring rests with the employees because the organisation only makes and announces the decision while the implementation of the changes is carried out by employees highlighting how the involvement of the implementers is of paramount importance to the success of any change initiative. Gondolfi (2013) explains how employee involvement programs ensure acceptance of labour cost reduction strategies and how they create the desire to assist the organisation in the labour cost reduction efforts within employees. Braegger et al. (2015) found that employees who were actively engaged in layoff processes receiving career counselling and job search assistance had improved perception of the fairness of the labour force reduction exercise. Braegger et al. 
(2013) further indicate how employees perceive layoffs as fair and reasonable if they are engaged in discussions leading to the layoffs and are aware of the criteria to be used prior to the layoff process.

On the other hand, Lahiri (2015) suggests that employee involvement in programs increases the expense burden of an organisation while the practise raises concerns about job security among employees which leads to ineffective worrying employees, proving to be costly to productivity and as an additional expense. Lam (2015) supports Lahiri (2015)'s view declaring that involving employees in talks or discussions around layoffs increases employee's perception of job insecurity compared to employees who were unaware of the impending layoff. He enunciates how involving employees in layoff discussions will lead employees to worrying about their jobs instead of empowering them. Zvonicek (2012) supposed that management are risk averse when it comes to involving employees in discussions on implementation of change strategies as they fear that employees may react negatively or protest before a decision is made and management are not interested in increasing costs by facilitating workshops or forums. Rehman and Naeem (2012) assert that merely talking about forthcoming layoffs is stressful.

Employee involvement in organisational redesigning and change has had mixed results. Although employee participation may seem like a positive step to reduce resistance, the resistance thought and feeling within employees is depended on their level of organisation based self-esteem (Lahiri, 2015). Greenbaum et al. (2012) concur that the ability an employee has to adhere to organisational change depends on their personal core self-evaluation. Even though positive stimuli such as involvement in decision making processes can lead to improved behaviour in employees, inertia as a characteristic of employees and systems prohibits ruling out employee resistance as an attempt to thwart any change initiative by the organisation (Reynaud, 2017). This is supported by Norman et al. (2013) expressing how matters such as employees' level of education can lead to variation of employees' empathy of managements' justification of labour force reduction during the discussion. The mixed findings and notions on employee involvement as a critical factor to facilitate successful implementation of labour force reduction initiatives have pushed the researchers to investigate the factors that influence the success of labour force reduction in manufacturing companies in a developing country.

Communication: Formal and informal communication with and among employees improves employees' commitment to changes such as labour cost reduction programmes as this clarifies grey areas that might be causing concerns among employees (Appelbaum et al., 2017). Lahiri (2015) asserts that early communication diminishes the feeling of uncertainty among employees and limits the possibility of exaggerated rumours wreaking havoc on the upcoming change process of reducing labour costs. Norman et al. (2013) further add that maintaining a steady accurate flow of information is key to diminishing resistance to change to come. Leadership's vision for the organisation must be effectively communicated to improve employees' readiness to accept change as this assists management and the employees to operate in unison as they are both aware of the desired results of the change initiative of reducing labour force costs (Haque et al., 2016). Sahoo (2014) accentuates that workshops within organisations must be held to provide information pertaining to imminent layoffs enhance trust. Greenbaum et al. (2012) affirm that providing honest information prior and during a downsizing exercise raises trust within the remaining employees. Employees who receive notice in reasonable time and explanations as to the causes and proceeding of downsizing exercises perceive labour force reduction exercises as being fair and have the aptitude to accept the outcome of the entire process (Braegger et al., 2015).

Although companies try to communicate layoffs in a positive light to employees pointing out how it was the last resort, the question still remains whether employees perceive it this way given declined performance of employees whose co-workers were fired during the process. This shows how communication is not understood even though management makes efforts to avoid negative communication (Norman et al., 2013). Invernizzi (2012) emphasizes that poorly managed communication can actually worsen the results of the change process as it results in resistance to change. Grebe (2013) highlights that management trying to conceal its failure to address matter leading to the organisations need to reduce labour costs by communicating labour force reduction in a positive light as doing so aggravates employees and exacerbates the situation. Lam (2015) accentuates that employees that know about an imminent catastrophe such as layoffs have diminished job security which increases inefficiency and mistakes at work. 
Norman et al. (2013) took a neutral stance accentuating that communication may improve employees' understanding of the process and reason for the move. They further enunciated how different individuals in the same organisation can perceive a communicated message differently during labour force reduction exercises. This highlights how an effective announcement can yield mixed results within the same organisation. Communicated labour force reduction can alert employees of potential psychological violation responses to the psychological violation varies dependent on the level of subjection, orientation and mastery orientation of the individual (Arshad, 2016). Given the equivocal literature on the effectiveness of communication as a factor to successfully implement labour cost reduction techniques, the research seeks to uncover effects of communication on successful labour force reduction in a developing country.

Employees' response to labour force reduction: Employees react to labour force reduction programmes differently. The following section seeks to review literature on employees' responses to labour force reduction paying attention to employees' feelings, job insecurity, organisational commitment, moral and stress. Employees working in organisations that underwent labour force reduction routines reported increased mistakes and distraction during the discharge of their duties (Fraher et al. 2013). They further underlined the cost of labour force reduction on an organisation pointing out that employees that experienced layoffs and Furloughs had increased levels of stress, frustration and anger resulting in diminished trust in the organisation and reduced moral to undertake their duties. Bryson et al. (2013) outlined that labour related organisational change is significantly associated with increased errors and mistakes within the workplace as employees are consciously and unconsciously acting on the amplified stress and anxiety feeling within them which negatively affect one's behaviour. Halbesleben et al. (2013) emphasise that labour force reduction measures exert immense emotional nervous tension on employees leading to augmented emotional fatigue, which explains the poor performance exhibited by survivors of downsizing exercises. Survivors reduced their performance by $43 \%$ after the downsizing exercise owing to their perception of the employer's loyalty and psychological contract violation (Norman et al., 2013).

Rehman and Naeem (2012) pointed out that organisational downsizing affected employees' commitment to their organisation negatively noting an increases in employees' sense of insecurity therefore decreasing the employees' dedication to stay with the organisation. This is supported by Halbesleben et al. (2013) who found that high performing employees had increased staff turnover intentions following labour cost reduction methods, the very same exceptional employees an organisation tries to secure. Darvishmotevali and Kilic (2017) emphasized how layoff survivors experience anxiety. Halbesleben et al. (2014) drew attention to employees' tendency to redirect their attention from the workplace to family and personal affairs after experiencing labour cost reduction exercises increasing employees' propensity to resign. Despite the negative employee feelings and responsive behaviours, there was notable positive responses seen in labour cost reduction survivors. During labour reduction exercise, employees console each other with the fact that they are going through the process together. Psychologically, each individual comes to terms with the fact that they will be left fighting for limited positions within the organisation, cultivating competitiveness among employees. This justifies positive surges in performance per employee as employees try to prove their worth to their employers (Norman et al., 2013). Hamed et al. (2013) support the view as they found that efficiency per employee increased after downsizing exercises. Ahn (2015) accentuated that employees' perception of control over situations affect their propensity to seek for new employment. External factors such as layoffs, and furloughs trigger awareness in the minds of employees that their employment status is out of their control enhancing their loyalty to an organisation and shattering turnover intentions as they feel that they are fortunate to be a labour force reduction survivor and no other organisation would accept them (Ahn, 2015). Labour force reduction involves the discontinuing organisational norms and routines inherently disrupting individuals' knowledge.

Tomprou et al. (2015) and Wei (2015) affirm that although labour cost reduction event shatter psychological contracts from employees' perspective. This does not guarantee employees acting upon the psychological contract change. Survivors of labour force and cost reduction exhibit mixed reactions which vary from positive reaction, negative reaction to no reaction at all depending on workforce characteristics (Norman et al., 2013). Arshad (2016) postulates that, employees' responses to labour cost reductions vary with individuals of different mind sets which can result in employees exhibiting mixed responses within one organisation. Cultures vary among nations. Asian nationals are used to lifetime employment and lifetime 
contracts with their employers while American nationals are used to moving from job to job seeking better contracts and employment conditions. With this in mind, labour force reduction exercises in America might not trigger any positive or negative response from surviving employees. The diverse reactions demonstrated by employees in the various studies on employees' responses to labour force reduction prompted the researchers to investigate the problems manufacturing companies in a developing country encountered.

The effects of employing Labour Cost reduction on Production Efficiency: The high level of labour cost reduction bustle globally indicates managements' beliefs with regards to the positive productive efficiency to be gained from the strategy (Datta and Basuil, 2015). The researchers will review the effects of labour cost reduction practises on the production efficiency of an organisation looking into organisational turnaround literature and downsizing literature paying close attention to layoffs, furloughs, outsourcing and restructuring.

Production time: In an attempt to isolate the effects of labour cost reduction from the influence of economic hardships, De Meuse and Dai (2013) conducted an empirical study on downsizing firms in a developing economy. The results showed improved production efficiency. In an empirical study investigated by Kavadis and Castaner (2015) results showed that in times of poor performance, organisations that employed restructuring as a labour cost reduction method improved the performance of their organisations mitigating the inefficient bottle necks of tall organisational structures and redundant skills within an organisation. Garnero et al. (2016) emphasized that organisations' on and off employment techniques have a strong positive relationship on the production efficiency of an organisation, Conversely, Goesaert et al. (2015) found that organisations that reduced their labour cost with the intent of increasing production efficiency experienced great declines in production efficiency with production taking longer than it did prior to downsizing. While organisations that cut labour costs due to economic hardship only faced a disdaining drop in productive efficiency during the labour cost reduction exercises. The drop is closely related to lower employee morale and motivation to tackle tasks at the efficient rate they used to take them prior to the downsizing event (Goesaert et al., 2015).

Cost reduction methods associated with labour have a negative effect on the likely-hood of an organisation recovering from diminishing productivity and performance suggesting the inappropriateness of labour force reduction as a measure to improve production efficiency (Ndofor et al. 2013). The disruptive result inherent to labour force reduction disrupts collective knowledge which is equivalent to a workforce that collectively forgets how to operate. This produces permanent detrimental effects on productivity of an organisation (Anderson and Lewis, 2014). Miller et al. (2012) affirm indicating how labour force reduction disrupts an organisations' ability to perform established routines which result in a drop in operating efficiency. The greater the portion of employees laid off the greater the operational efficiency damage. Labour force reduction upsets social network and periphery structure of an organisation. The two dynamics are essential to efficiency in tackling internal and external issues namely productivity communication and sales, interrupting already developed and normative dynamics shrink production efficiency of an organisation (Schenkel and Teigland, 2017). Rehman and Naeem (2012) emphasized how labour cost exercises are detrimental to the productive efficiency of individual employees and ultimately the production efficiency of the organisation as a whole. Rahman and Naeem (2012) further added that labour retrenchment strategies as labour cost techniques are detrimental to the production efficiency of an organisation, further pointing out that 'cure' of workforce reductions are costly than the supposed 'disease'.

Datta and Basuil (2015) assert that the result of downsizing of the production efficiency of an organisation is contextual dependent on factors such as culture, firm to employee relationship and timing. This means that different organisations can reap different results from implementing labour force reduction techniques as a cost reduction measure. Lahiri (2016) agrees by highlighting how organisations employing the same labour force reduction technique can obtain varying production efficiency results from a negative, positive, moderate, mixed or no effect at all. Norman et al. (2013) suggest that the extent of the labour force reduction affects the results of the exercise. They stipulated that insignificant layoffs such as laying of three managers or supervisors in an international conglomerate may have no significant impact, while laying of $50 \%$ of an organisation workforce may improve efficiency by eliminating redundant out dated skills. Alternatively, if a similar organisation does the same, this might cut too deeply into an organisation and harm its efficiency. In 
light of the dissonance in findings and conclusions on the impact of labour force reduction on production efficiency, the researchers seek to ascertain how the practice affected the production efficiency of manufacturing companies operating in a developing country.

Employees workload: Implementation of labour force reduction methods such as layoffs result in an organisation having less employees to complete a task which forces employees to own up to tasks that were tackled by former employees (Chhiner and Currie, 2014; Rehman and Naeem, 2012). Chhiner and Currie (2014) indicated that organisations that downsize experience organisational productive growth while utilizing less human capital and increased operating profit per employee, pointing out how layoffs augment the production efficiency of organisations. Kavadis and Castaner (2015) emphasized that employment of restructuring activities leads to surges in productivity per employee as employees are challenged with new tasks that come with the new post that they attain after restructuring activities. After implementation of labour force reduction, activities such as layoffs and delayering employees' output is increased as they battle to attain and retain management and director's attention so they can avoid getting laid off or get positions of prominence after delayering exercises (Pearce and Robinson, 2015). This is also supported by Garnero et al. (2016) who pointed out that some employees go to lengths of requesting for additional tasks from management or supervisors in attempts to prove their value in the organisation. This creates a competitive environment which rubs off fellow employees improve output per employee notably (De Meuse and Dai, 2013; Oke and Kach, 2012; Tomprou et al., 2015; Zohrabi, 2013).

Hamed et al. (2013) found that employees' workload was increased with surviving employees taking up the workload of employees that had left the organisation, which meant that organisations could enjoy the production of about the same number of units with a significantly lower number of employees. Conversely Anderson and Lewis (2014) found that layoffs, furloughs and restructuring activities that are involved in labour force reduction activities result in employees forgetting how to tackle certain tasks they used to complete in teams after one or more of their co-workers is laid off. Anderson and Lewis (2014) added that once key team members from teams are removed, the number of units produced per employee drops and the drop is especially pronounced in the immediate and short term basis. Ko and Yeh (2013) emphasized that reducing an organisation's labour force diminishes employees' job satisfaction and motivation which results in employees slacking and absorbing less work. Shepherd (2017) noted that employees' zeal to complete tasks is shattered when they experience the loss of co-workers through labour force reduction especially when the memories are fresh on their mind.

Drensky and Heinz (2014) emphasized that labour force reduction on its own is not sufficient to hinder employees from tackling the tasks they used to tackle before labour force reduction. Ko and Yeh (2013) also added that labour force reduction initiatives cannot scare an employee into taking on new responsibilities in the workplace. According to Drensky and Heinz (2012), employees take up new jobs, however, the fear of losing their job hinders the employees' ability to tackle the tasks they take up neutralising the workload increase that was hoped for. Datta and Basuil (2015) in their research pointed out that employees' response to labour force reduction varies dependent on the employee's opinion of the exercises fairness. Research on labour force reduction and employees' propensity to work harder and take on more workload has had varying findings and this has pushed the researchers to investigate how labour force reduction affected production efficiency, paying close attention to employees' efficient completion of tasks in Zimbabwe's Manufacturing industry.

Labour Force reduction relationship with Rota: In the following section, the researchers will review empirical literature on labour force reduction and its impact on financial performance. Profitability is widely accepted as a measure of financial performance with ROTA and ROE being the measures of profitability (Gandolfi, 2013). ROTA is the most effective measure of financial performance as companies usually reduce their labour force in an attempt to reduce payroll costs and improve their profit margins. Therefore, measuring the change in profit as a percentage of sales can give a reflection of the financial performance amelioration or deterioration in value creating organisations (Brauer and Laamanen, 2014). If all things are held constant that is revenue and assets are held constant, labour force reduction reduces operational costs meaning ROTA should increase (De Muese and Dai, 2013). The following section will pay particular attention to literature that used ROTA as a measure of financial performance. 
Brauer and Laamanen (2014) found that smaller (5\% - 14\%) labour force reduction resulted in significant $4 \%$ to $8 \%$ increases in ROTA as payroll costs are decreased without disrupting organisational routines of the organisation while larger (30\% - 40\%) labour force reduction exercises improved organisational ROTA by $2 \%-13 \%$ due to the major changes and interference with organisational routines. The percentage difference of the positive effect of downsizing is attributable to the labour force reduction rational with organisations that implemented downsizing reactively to diminishing performance reaping low performance increments than their proactive counterparts that downsized offensively to improve efficiency (Brauer and Laamanen, 2014). Raynaud (2012) found that reducing labour force was positively associated with increases in an organisation's ROA in both the short (one year) medium (3 years) and long term (5 years) at a steady climb. The positive result was more prominent in non-listed organisation as they give precedence to economic rather that accounting figures (Reynaud, 2013). De Meuese and Dai (2013) noted an improvement in ROTA in the year of labour force reduction and a continuous upward trend post labour force reduction reflecting the positive relationship between downsizing and firm performance. Jung et al. (2017) found that American corporations that undertook efficient layoffs saw positive increments in ROTA in two subsequent years hinting towards a positive relationship between labour force reduction and ROTA.

Conversely, Luan et al. (2013) found that reducing the labour force in both economic hardship and prosperity was negatively related to ROTA, while reducing an organisations' work force during economic recession proves to be more detrimental to an organisations ROTA. Although downsizing reduces operating costs through cutting wages and salaries, they resulted in organisations wrong sizing themselves by cutting operating capacity (Luan et al., 2013). Ndofor et al. (2013) pointed out how retrenchment activities such as layoffs lead to a decline in ROTA in the year of labour force reduction and the following year and no further noteworthy increases or decreases. This shows how retrenchment such as layoffs in an attempt to turnaround an organisation prove to be costlier than the payroll savings and having a negative relationship to ROTA. Abraham et al. (2013) noted a negative relationship between labour force reduction and downsizing with organisations that performed poorly having a severe decrease in ROTA while better performing firms experienced minor decreases in ROTA. The timing of labour force reductions influences the possibility of turnaround success while late layoffs are negatively related to increases in ROTA (Tangpong et al., 2015). Chhiner and Currie (2014) established that excuse, justification, denial and apology based labour force reduction had a negative relationship with ROTA. They further highlighted that labour force reduction resulted in a sharp decline in ROTA in the year of downsizing for the four rationales behind labour force reduction and a steady rise in the subsequent two years with the rise never exceeding the post labour force reduction Ratio.

Labour force reduction is not necessarily limited to resulting in a positive or negative effect on ROTA. Carriger (2016) in his empirical research found that companies that reduced their human capital had no noteworthy increases or decreases in ROTA. ROTA was not affected and the labour force reduction strategy made no significant impact on efficiently using available assets (Carriger, 2016). After conducting an empirical investigation, Hamed et al. (2013) asserted that there was no relationship between labour force reduction and ROTA seeing as there were no notable difference between post and pre labour force reduction ROTA ratio. Gandolfi (2013) supports the notion as he established that labour force reduction had no significant impact on organisations' ROTA ratio. Research on the relationship between labour force reduction and financial performance measure by ROTA has been inconclusive with contrasting results incentivising the researchers to conduct an empirical study to investigate the impact of labour force reduction on the financial performance of manufacturing organisations operating in a developing country. The next study shall therefore be based on a follow up empirical research.

\section{Conclusion}

From the literature reviewed, the study established that methods used for labour force reduction are layoffs, furloughs, outsourcing and delayering. Of the four methods literature revealed that furloughs were the most effective method to reduce labour force and improve financial performance. The second most effective method of labour force reduction to improve financial performance as measure was layoffs. Outsourcing contrary to layoffs and furloughs proved to be detrimental to financial performance as measure. In addition, the researchers made critical evaluations of results, findings and conclusions of empirical and qualitative 
research around labour force reduction. The study established that labour force reduction did not have the same effect on employees. It also emerged that labour force reduction did not result in increased employee turnover. The study concludes that reducing innovative employees responsible for the production of new break through products is detrimental to the production efficiency of producing new products however reducing human capital responsible for the production of homogenous products results in improved production efficiency.

\section{Recommendations: The study recommends that:}

- Organisations facing inefficiency within the organisation should consider laying off employees with their hands of the deck and delaying their organisational structure to reduce excess deadweight.

- Organisations should actively engage employees in discussions pertaining to labour force reduction prior to and during labour force reduction to ensure that employees understand management and directors vision and they do not face a drop in production efficiency in the short run.

- Organisations should ensure that they adequately communicate labour force reduction exercises prior to and during labour force reduction exercises to re-assure employees that their jobs are secure and to boast their morale.

\section{References}

Abraham, S. E., Khan, R. \& MacDonald, J. A. (2013). Layoffs and Long Term Firm Financial Performance: The BRC Academy. Journal of Business, 3(1), 1-17.

Agrawal, P. \& Haleem, A. (2013). The impact of the out- sourcing of IT on firm performance: an empirical study. International Journal of Management, 30(4), 121-139.

Agrawal, P. \& Hall, S. C. (2014). Using accounting metrics as performance measures to assess the impact of information technology outsourcing on manufacturing and service firms. Journal of Applied Business Research, 30(7), 1559-1568.

Ahn, T. (2015). Locus of Control and Job Turnover. Economic Inquiry, 53(2), 1350- 1365.

Anderson, E. \& Lewis, K. (2014). A dynamic model of individual and collective learning amid disruption. Organization Science, 25(2),356-376.

Antonioli, D., Mazzanti, M., Montresor, S. \& Pini, P. (2015). Outsourcing and Film Productivity in a Specific Local Production System: Evidence from Reggio Emilia (Italy). Growth and Change, 46(2), 292- 320.

Appelbaum, F. R., Büchner, T. \& Dombret, H. (2017). Factors that impact the success of an organisational change: a case study analysis. Industrial and Commercial Training, 49(5), 213- 230.

Appelbaum, F. R., Büchner, T. \& Dombret, H. (2017). Resistance to change in the case of mergers and acquisitions: part 1. Industrial and Commercial Training, 49(2), 87-92.

Arshad, R. (2016). Psychological contract violation and turnover intention: Do cultural values matter? Journal of Managerial Psychology, 31(1), 251-264.

Arvanitis, S. \& Loukis, E. N. (2012). Outsourcing and firm performance - a comparative study of Swiss and Greek firms. Industrial and Corporate Change, 22(3), 771-806.

Ashman, I. (2016). Downsizing: Managing redundancy and restructuring. Reframing Resolution,3(7), 149-164.

Bellairs, T., Jonathon, R. B. \& Leon, M. R. (2014). A multilevel model of strategic human resource implications of employee furloughs. Research in Personnel and Human Resources Management, 32(5), 99-146.

Boddy, C. R. (2016). Sample size for qualitative research, Qualitative Market Research: An International Journal, 19(4),426-432.

Braegger, C., Campoy, C., Colomb, V. \& Decsi, T. (2013). Giving Nonselective downsizing a performance review. Human Resource Development Review, 20(10),1-21.

Braegger, C., Campoy, C., Colomb, V. \& Decsi, T. (2015). Factors Affecting Perceptions of Procedural Fairness of Downsizing: A Policy Capturing Approach. Human Resource Development Quarterly, 26(2),127 154.

Brauer, M. \& Laamanen, T. (2014). Workforce downsizing and firm performance: an organisation routine perspective. Journal of Management Studies, 51(8),65-83

Bryson, A., Barth, E. \& Dale-Olsen, H. (2013). The Effects of Organisational Change on Worker Well-Being and the Moderating Role of Trade Unions. ILR Review, 66(4), 989-1011.

Carriger, M. (2016). To downsize or not to downsize - what does the empirical evidence suggest? Journal of Strategy and Management, 9(4),449-473. 
Chhiner, N. N. \& Currie, E. (2014). Assessing longitudinal relationships between financial performance and downsizing. Management Decision, 52(8),1474- 1490.

Cuillan, C. P. \& Zheng, X. (2017). Accounting outsourcing and audit lag, Managerial Auditing Journal, 32(3), 276- 294.

Darvishmotevali, M., Arasil, H. \& Kilic, H. (2017). Effect of job insecurity on frontline performance. International Journal of Contemporary Hospitality Management, 29(6), 1724-1744.

Datta, K. D. \& Basuil, D. A. (2015). Does Employee Downsizing Really Work. Human Resource Management Practices. Springer International Publishing Switzerland,4(4), 197 - 221.

DeMeuse, K. P. \& Dai, G. (2013). Organizational downsizing: Its effect on financial performance. Online Journal of Managerial Issues, 25(4), 324-344.

Drensky, F. \& Heinz, M. (2014). The Hidden Costs of Downsizing. The Economic Journal, 126(7), 2324- 2341.

Fraher, A, L. (2013). Airline downsizing and it impact on team performance. Team Performance Management: An International Journal, 19(1/2),109-126.

Gandolfi, F. (2013). Employee Downsizing of the Banking Sector in Portugal: A Case Study. Journal of Modern Accounting and Auditing, 9(8),1105-1118.

Garcia - Cabrera, A. \& Hernandez, F. G. (2014). Differentiating the Three Components of Resistance to Change: The Moderating Effect of Organization- Based Self-Esteem on the Employee Involvement - Resistance Relation. Human Resource Development Quarterly, 25(4), 441 - 469.

Garnero, A., Giuliano, R., Mahy, B. \& Rycx, F. (2016). Productivity, wages and profits among Belgian firms: do fixed- term contracts matter?' International Journal of Manpower, 37(2), 303-322.

Gensler, L. (2016). Profits Are Still Tumbling at America's Big Oil Companies. Forbes Available at: http://www.forbes.com/sites/laurengensler/2016/10/28/exxonmobilchevron-earnings-oil-prices2/\#5cde1e5c18e8< (Retrieved 30 October 2017)

George, J. M. (2014). Compassion and capitalism: Implications for organizational studies. Journal of Management, 40(1), 5-15.

Goesaert, T., Heinz, M. \& Vanormelingen, S. (2015). Downsizing and firm performance: Evidence from German firm data. Industrial and Corporate Change, 24(6),1443-1472.

Grebe, K, S. (2013). The importance of being genuinely sorry when organisations apologise: how the Australian Wheat Board (AWB Limited) was damaged even further by its response to a corporate scandal. Journal of Public Affairs, 13(1),100- 110.

Greenbaum, R. L., Mawritz, M. B. \& Eissa, G. (2012). Bottom-line mentality as an antecedent of social undermining and the moderating roles of core self-evaluations and conscientiousness. Journal of Applied Psychology, 97(2), 343-59.

Habel, J. \& Klarmann, M. (2015). Customer reactions to downsizing: when and how is satisfaction affected? Journal of the Academic Marketing Science, 43(6), 768-789.

Halbesleben, J. R. B., Bellairs, T. \& Mandeville, A. M. (2014). A meaning maintenance model of impact of furloughs on family.' Paper presented at the 2014 Society of Industrial and Organizational Psychology conference, Honolulu, HI.

Halbesleben, J. R. B., Wheeler, A. R. \& Paustian- Underdahl, S. (2013). The impact of furloughs on emotional exhaustion, self-rated performance, and recovery experiences. Journal of Applied Psychology, 98(3), 492-503.

Hamed, W., Bowra, A. B., Aleem, M. \& Hussain, A. (2013). An Empirical investigation of downsizing a study of banking sector of Pakistan. African Journal of Business Management, 7(17), 1640-1647.

Han, K. \& Mithas, S. (2013). Information technology outsourcing and non-IT operating costs: an empirical investigation. MIS Quarterly, 37(6), 315-331.

Haque, M., Titi Amayah, A. \& Liu, L. (2016). The role of vision in organizational readiness for change and growth. Leadership \& Organizational Development Journal, 37(7), 983-99.

Ho, C. \& Wei, C. (2016). Effects of outsources service providers' experiences on perceived service quality. Industrial Management \& Data Systems, 116(8), 1656-1677.

Holtom, B. C. \& Burch, T. C. (2016). A model of turnover-based disruption in customer services. Human Resource Management Review, 26(1),25-36.

Invernizzi, E., Romenti, S. \& Fumagalli, M. (2012). Identity, communication and change management in Ferrari. Corporate Communication: An International Journal, 17(4), 483-97.

Ivancevich, J. \& Konopaske, R. (2013). Human resource management 12th edition Singapore: McGraw-Hill 
Jung, B., Kim, B., Lee, W. \& Yoo, C. (2017). Are Layoff Decisions of American Corporations Efficient? KAIST College of Business Working Paper Series No. 2016-001. Journal of Human Resource Management, 24(7), 1519-1535.

Kavadis, N. \& Castañer, X. (2015). Who drives corporate restructuring? Co- Existing owners in French firms. Corporate Governance: An International Review, 23(5), 417- 433.

Ko, J. R. \& Yeh, Y. Y. (2013). Worker satisfaction following employment restructuring: Effects of Nonstandard workers and downsizing on job satisfaction in Taiwan. Springer Science + Business, 110, 453-467.

Lahiri, S. (2016). Does Outsourcing Really Improve Firm Performance? Empirical Evidence and Research Agenda. International Journal of Management Reviews, 18(5),464- 497.

Lam, A., Fox, K., Fan, W., Moen, P., Kelly, E. \& Hammer, L. (2015). Manager Characteristics and employee job insecurity around a merger announcement: the role of status and crossover. The Sociologist Quarterly, 56, 558-580.

Lee, S.\& Sanders, R. M. (2013). Fridays Are Furlough Days the Impact of Furlough Policy and Strategies for Human Resource. Management During a Severe Economic Recession, 33(3),299-311.

Lu, Y., NG, T. \& Tao, Z. (2012). Outsourcing, Product Quality, and Contract Enforcement. Journal of Economics and Management Strategy, 2(1), 1-30.

Luan, C. J., Tien, C. \& Chi, Y. C. (2013). Downsizing to the wrong size? A study of the impact of downsizing on firm performance during an economic downturn. International Journal of Human Resource Management, 24(7), 1519-1535.

Mathies, U. (2016). Panasonic: A case study on Constant Change and Reinvention of a World Brand.' Retrenchment and Recovery. Journal of Management Studies 50(7), 34-98.

Miller, K. D., Pentland, B. T. \& Choi, S. (2012). Dynamics of performing and remembering organizational routines. Journal of Management Studies, 49(8), 1536-1558

Mugabe, N. (2017). Airzim retrenches 200 workers' The Herald 18 July [Online] Available at; http://www.herald.co.zw/airzim-retrenches-200-workers/ accessed on 18 July 2017

Ndofor, H. A., Vanevenhoven, J. \& Barker, V. L. (2013). Software firm turnarounds in the 1990s: An analysis of reversing decline in a dynamic industry. Strategic Management Journal, 34(9), 1123-1133.

Norman, P. M., Butler, F. C. \& Ranft, A. L. (2013). Resources matter: Examining the effects of resources on the state of firms following downsizing. Journal of Management, 39(7), 2009-2038.

Oke, A. \& Kach, A. (2012). Linking sourcing and collaborative strategies to financial performance: the role of operational innovation. Journal of Purchasing and Supply Management, 18(6), 46-59.

Oke, A. \& Onwuegbuzie, H. (2013). Outsourcing, subcontracting and radical innovativeness: the moderating effect of manufacturing strategy. Journal of Manufacturing Technology, 24(4), 511-535.

Pearce, J. \& Robinson, R. (2015). Strategic management: planning for domestic and global competition 14th edition Singapore: McGraw-Hill

Powell, R. \& Yawson, A. (2012). Internal restructuring and film survival. International Review of Finance, $12(4), 435-467$.

Rehman, W. \& Naeem, H. (2012). The impact of downsizing on the performance of survived employees: A case study of Pakistan. African journal of business management, 6(7), 2429 - 2434.

Reynaud, B. (2013). Workforce reduction and firm performance: Evidence from French firm data. SocioEconomic Review, 11(4), 711-737.

Richter, M. \& König, C. J. (2016). Explaining individuals' justification of layoffs. Journal of Applied Social Psychology, 47(3), 331-346.

Sahoo, C. K. (2014). HR powers turn-around at Talcher thermal plant. Human Resource Management International Digest, 22(4), 16-18.

Schenkel, A. \& Teigland, R. (2017). Why doesn't downsizing deliver? A multi-level model integrating downsizing, social capital, dynamic capabilities, and firm performance. The International Journal of Human Resource Management, 28(7), 1065-1107.

Shepherd, R. L. (2017). Federally Mandated FURLOUGHS: The Effect on Organizational Commitment and Organizational Citizenship Behavior. Defence Acquisition Research Journal: A Publication of the Defence Acquisition University, 24(1), 162-189.

Tangpong, C., Abebe, M. \& Li, Z. (2015). A temporal approach to retrenchment and successful turnaround in declining firms. Journal of Management Studies, 52(5), 34-45.

Tomprou, M., Rousseau, M. D. \& Hansen, S. D. (2015). The Psychological contracts of violation victims: A postviolation model. Journal of Organisational Behaviour, 36,561-581. 
Vapnek, J. (2017). Cost-Saving Measures for the Judiciary. International Journal for Court Administration, 4 (4), 45-65.

Wei, X. (2015). Understanding Psychological contract breach due to labour cost reduction: contingent upon employee sex and managerial control. Journal of Occupation and Organisational Psychology, 88, 679701.

Weigelt, C. \& Sarkar, M.B. (2012). Performance implications of outsourcing for technological innovations: managing the efficiency and adaptability trade-off. Strategic Management Journal, 33(4), 189-216.

Wickford, R. (2016). Strategic Human Resource Planning. Second Edition. Canada: Thomson Learning

Yu, M., Chern, C. \& Hsiao, B. (2012). Human resource rightsizing using centralized data development analysis: Evidence from Taiwan's airports, 41(1), 119-130.

Zohrabi, M. (2013). Mixed method research: Instruments, validity, reliability and reporting findings. Theory and Practice in Language Studies, 3(2),254-276.

Zorn, M. L., Norman, P. M., Butler, F. C. \& Bhussar, M. S. (2017). Cure or curse: Does downsizing increase the likelihood of bankruptcy? Journal of Business Research, 76(5), 24-33.

Zvonicek, R. A. (2012). A study of the California furloughs and their effects on state workers. California: California university'. 